International

Journal of

Sudan Research

V8, N2

2018

\title{
VALUE CHAIN MODEL OF MANURE MANAGEMENT IN DAIRY FARMS IN KHARTOUM, SUDAN
}

\author{
Amira A. Ahmed* \\ University of Khartoum, Faculty of Animal Production, \\ Department of Dairy Production, \\ Khartoum North, \\ Sudan \\ Nahid M.T. Fawi \\ University of Khartoum, Faculty of Animal Production, \\ Department of Dairy Production, \\ Khartoum North, \\ Sudan \\ Email: nahidfawi@gmail.com
}




\section{ABSTRACT}

Purpose: This study aimed to analyse the value chain of manure management in dairy farms in different areas in Khartoum, Sudan. Research was based mainly on primary data collection using a cross-sectional scientifically structured questionnaire that targeted the owners of the dairy farms.

Design/Methodology/Approach: A judgmental non probability sampling method was performed where a total of 70 farms scattered at various geographical locations in Khartoum North constituted the sample of the research. The collected data was analysed using the computerised Statistical Package for Social Sciences (SPSS ver., 11.5) to obtain the frequency of distributions, further the obtained data was used to map a value chain model for manure management in the dairy farms under study.

Findings: Main results obtained showed that $57.1 \%$ of the dairy farmers collected manure from barns $>$ once per week; $55.7 \%$ of the farms produced $2-6$ tons of manure / month; $47.1 \%$ of the dairy farmers sold manure 4 times /month. Most of the owners $88.6 \%$ did not use manure as fertiliser in their farm.

Conclusion upon Through Analysis: The study was concluded with several recommendations to upgrade the manure management value chain; where Dairy farmers, especially in the traditional sector should be encouraged to value manure as an added value product rather than a waste product; thus increasing the overall farm profitability, further there is strong need for crafting business oriented extension packages that target dairy farmers to leverage their awareness level regarding manure collection, storage, treatment and marketing strategies.

Keywords: Value chain model; Dairy farms; Manure management; Added value product; Khartoum; Sudan

\section{INTRODUCTION}

Livestock sector contributes to the livelihood of millions of people; nevertheless their production poses several environmental challenges such as greenhouse gas emissions, eutrophication, acidification and biodiversity loss (Mottet et al., 2017). Livestock can help transfer and convert proteins from plant biomass (e.g. grass or by-products, range lands or food waste) into animal-sourced foods utilising resources that otherwise cannot be consumed by humans, but in other cases livestock production is in competition with other land uses such as food, fiber and energy production (Van Zanten et al., 2018). A value chain refers to the full life cycle of a product or process, including material sourcing, production, consumption and disposal/recycling processes (WBCSD, 2011). (Porter, 1985) in his book on Competitive advantage defined a value chain as a systematic approach to examine the development of competitive advantage. The Global Value Chains Initiative defined the value chain as the full range of activities that firms and workers do, to bring a product from it's conception to it's end use and beyond this includes activities such as design, production, marketing, distribution and support to the final consumer (www.koganpage.com, 2016). The livestock value chain can be defined as the full range of activities required to bring a product: for example, live animals, meat, milk, eggs, leather, fiber or manure to its final consumers, passing through the different phases of production, processing and delivery. It can also be defined as a marketfocused collaboration among different stakeholders who produce and sell value-added products (IFAD, 2007). The key players in the value chain are the input suppliers, farmers of various sizes, milk collection centers, processors and retail outlet, each of these players in the value chain carry out various value adding services. The primary producer in the dairy value chain, the farmer carries various animal husbandry measures such as disease control measures, provision of feed to in-calf and lactating cows to ensure that the raw milk produced meets 
standard requirement and traded through the formal marketing channels (Achchuthan and Kajananthan, 2012), thus Value chain analysis plays a key role in understanding the need and scope for systemic competitiveness. The analysis and identification of core competences will lead the firm to outsource those functions where it has no distinctive competences (Kaplinsky and Morris, 2002). Value chain analysis is essential to an understanding of markets, their relationships, the participation of different actors, and the critical constraints that limit the growth of livestock production and consequently the competitiveness of smallholder farmers (Achchuthan and Kajananthan, 2012). Manure in farms is a valuable resource and can be used for multiple purposes as fertiliser for crop production and improved soil health, a source of energy, or as basis for construction material while manure is a valuable source of nutrients and renewable energy, if poorly managed it poses serious human health and manure quality is a function of its management (Ewusi-Mensah et al., 2015). Manure management plans require knowing the amount of manure produced, collected and available for land-spreading whereas much information is available to calculate manure production, Little is known about the types and amounts of manure actually collected on typical dairy farm (Powell et al., 2005). Depending on individual preferences and existing equipment that may already be in place, every dairy farm has different manure handling needs and challenges there is no single best manure management system (MOA, 2015). On the other hand, marketing manure can be a beneficial, low-risk way for livestock producers to manage animal waste on their farms while incorporating a value-added product into their overall business plan. Livestock manure can become an important value-added co-product in just about any size operation. The two main goals of a successful value-added manure-marketing plan are to establish ready markets for excess manure and to keep operational costs low enough to make a profit from the sale of the manure product (NCAT, 2014). Added value also creates a higher profitability for an organisation and other stakeholders, a theory successfully applied by (Nabiswa and Siamba, 2017) on the effect of marketing strategies on the dairy value chain returns and food and nutrition security in Bungoma County, Kenya where the key players in the value chain were the input suppliers, farmers, milk collection centers, processors, research institutions, quality regulator and retail outlets. This research aimed to elaborate the importance of manure as a profitable product rather than be looked upon by most dairy farms as a waste product requiring disposal in any way and at any price without reorganisation of its real value and proper usage when proper management and marketing strategies are wisely implied. The main objectives of the study were: to utilise animal manure from dairy farm as a real source of income; to provide a value chain model of manure management in dairy farms and to improve manure management strategies in dairy farm to reduce it's negative environmental and health effects.

\section{MATERIALS AND METHODS}

The study was performed during the period 2016 to 2017 in Khartoum North, which is the third largest municipality in Khartoum the capital of Sudan. It was chosen as an area for the research, as it contains the majority of dairy farms in the capital Khartoum. Research was based mainly on primary data collection using a cross-sectional, scientifically structured questionnaire that intended to meet the objectives and aims of the research, where dairy farm 
owners'resembled the target of the study. Due to the absence of definite official data concerning the actual number of dairy farms in Khartoum North and in addition to the sensitivity of the respondents to participate in the study for culture reasons, a judgmental non probability sampling method was performed where owners who were willing to contribute in the study were chosen as the sample of the study. A judgmental sampling is a form of convenience sampling in which the population elements are selected based on the researcher's judgment (Malhotra, 2014). A total of 70 farms constituted the sample of the research scattered at various geographical locations in Khartoum North (Shambat, Elhalfaia, Elkadro, Samrab, Elfaky Hashim, Haj Yousif, Hasania, East Soba). Since the variables were qualitative in nature, the collected data was analyzed using the computerised Statistical Package for Social Sciences (SPSS ver., $11.5)$ to obtain the frequency of distributions, further the obtained data was used to map a value chain model for manure management in the dairy farms under study.

\section{RESULTS AND DISCUSSIONS}

The results obtained upon statistical analysis in the form of frequencies were used to map a model for the value chain as illustrated in Figure 1. Regarding manure management strategies it was found that most dairy producers $(57.1 \%)$ collected manure from the barn more than

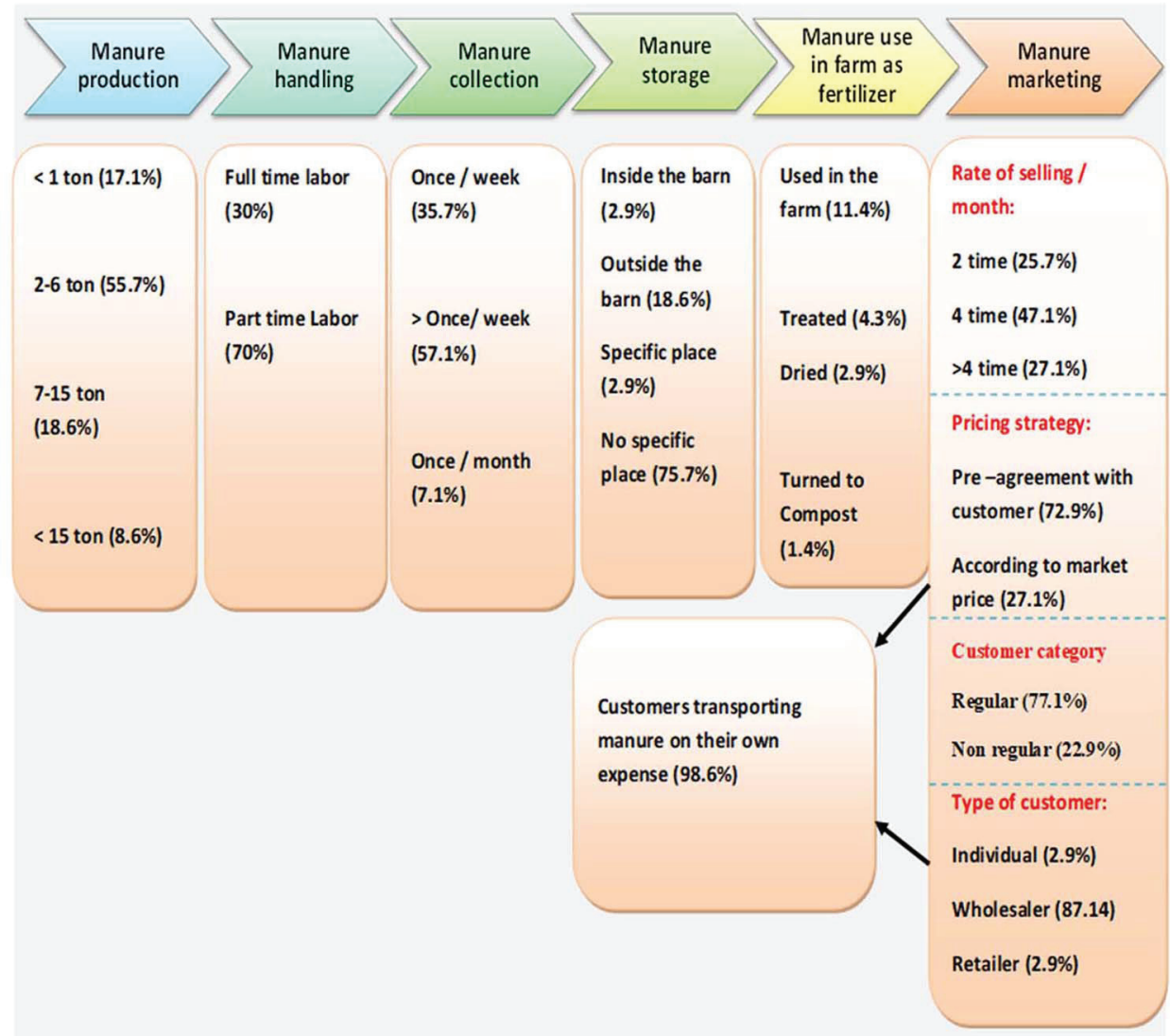

FIGURE 1 Value chain model of manure management in dairy farms under study 
once/week, while (35.7\%) collected manure once/week and only $(7.1 \%)$ collected manure once/month, this result indicates that the producers care about cleanness of the barn to avoid mal odours and diseases a result that agrees with (Kelly and Michael, 2014) who found that accumulated manure can cause health problems, odour and water quality problems if not properly dealt with. Regarding manure collection areas the majority of the producers $(75.7 \%)$ had no assigned place for manure collection, however $(24.3 \%)$ of the producers had an assigned place for manure collection where about $(18.6 \%)$ of them kept manure outside the barn $(2.9 \%)$ kept manure inside the barn and $(2.9 \%)$ kept manure in a specific place in the farm, this result could be explained by the fact that establishing a collection area is high costing compared to the absence of economic benefit from manure specially where the amount of manure produced is low from small sizes herd; furthermore producers sell manure on frequent bases thus there is no need for storage areas. This result disagrees with (Bourque and Koroluk, 2003) who indicate that the majority of all dairy farms (57.3\%) in Canada had solid/semi-solid manure storage systems, while $(42.7 \%)$ of dairy cattle used liquid manure storage systems. In terms of labour employed for manure collection (70\%) of the farms under study hired part time labourers, while only (30\%) used employed full time labour, this result could be explained by the selling strategy of manure implied in these farms where the costumers provide their own labours to collect purchased manure. On the other hand the quantity of manure produced/month on dairy farm showed that a percentage of $(55.7 \%)$ of the dairy farms produced 2-6 ton/month in comparison to (17.1\%) farms which produced $<1$ ton/ month, $(18.6 \%)$ produced 7 to 15 ton/month and only $(8.6 \%)$ produced $>15$ ton/month. The variation in manure quantity produced by the farms can be referred to by the effect of the different herd sizes, type of nutrition, age of animals, health status, a result that coincides with (Ogejo, 2005) who found that animal type, diet, animal age and environment affect the quantity of manure production. When studying the marketing strategies performed by the farm owner $(87.1 \%)$ of the farms sold their manure to wholesalers, $(7.1 \%)$ sold to both wholesalers and individuals, while $(2.9 \%)$ sold only to individuals and $(2.9 \%)$ sold only to retailers. The result revealed that wholesalers constituted the main customers of manure in dairy farms. (NCAT, 2014) found that due to large quantities of manure which was produced on a daily basis many of large farms find it feasible to contract with outside companies to supervise the removal and disposal of their manure and also install onsite facilities to convert the manure into a sellable product, or use it on their farms, moreover (Antony et al., 2013) indicated that livestock manure from rangelands is marketed through various channels, the four key parties involved were the pastoralists, brokers, farmers and horticultural farms. Furthermore (77.1\%) of the farm owners dealt with regular customers to purchase manure and this indicates that the owners of farms prefer to deal with a regular customer instead of different customers to ensure the continuous sale in the specified times, while only $(22.9 \%)$ dealt with non-regular customers. Regarding rate of manure selling in the farms under study $(47.1 \%)$ sold manure 4 times/month, while $(27.1 \%)$ sold $>4$ times/month compared to $(25 \%)$ who sold twice/ month. This result reveals the different husbandry practices in the farms and thus different quantities of manure produced. (Mustafa et al., 2011) reported that daily manure disposal by selling was practiced by the majority of farm householders $(87.8 \%)$ in Khartoum North. The pricing strategy of manure relies mostly on pre agreement with the purchaser where $(72.9 \%)$ of the farms adopt this strategy, while $(27.1 \%)$ depend on prevailing market price, this result indicates that the customer is in control regarding pricing strategies where price is based 
mainly on the quantity rather than the quality of manure. On the contrary (Leibold and Olsen, 2007) indicated that the most common method of valuing fertilisers is component pricing where the manure is sampled and tested to determine the nutrient content, then this analysis is used to determine the value based on commercial fertiliser prices. As for distribution strategies $(98.6 \%)$ of the farms indicated that customers (wholesaler, retailer, individual) transport manure on their own expense using lorries or donkey carts, a result that shows that farm owners value manure as an non profitable waste product that needs to be get rid of the minimum cost. (Muhereza et al., 2014) found that the major problems associated with manure included weight and bulkiness (75\%), lack of labour $(67.5 \%)$, insufficient quantities $(55 \%)$, high transportation and application costs $(37.5 \%)$. When studying manure treatment and usage in farms under study, $(88.6 \%)$ of the owners indicated they do not use manure as fertiliser in their farm while $(11.4 \%)$ use it, this could be explained by lack of farm land, increase the cost of labour and cost of equipments. Moreover, (7.14\%) used manure without any treatment, while $(4.3 \%)$ who used manure as fertiliser, use various types of treatment such as drying $(2.9 \%)$, where manure was dried for one month before use $(2.9 \%)$ while $(1.4 \%)$ dried manure for two months before use, $(1.4 \%)$ converted it to compost. This result could be explained by the fact that most farm owners prefer to use small ruminants manure (goat and sheep) for fertilisation instead of cattle manure due to its good texture, small size and slow decomposition compared to a cattle manure which needs to be dried or composted, thus increasing expenses, a result that coincides with (Harris, 2001) who found that the preference for the small ruminant manure is due to its fine texture, which makes it easy to apply, especially when they mix mineral fertilisers with manure to facilitate even distribution.

\section{CONCLUSION}

Upon thorough analysis the study had to highlight vital recommendations that could upgrade the manure management value chain, where Dairy farmers, especially in the traditional sector should be encouraged to value manure as an added value product rather than a waste product; thus increasing the overall farm profitability, further there is a strong need for crafting business oriented extension packages that target dairy farmers to leverage their awareness level regarding manure collection, storage, treatment and marketing strategies.

\section{BIBLIOGRAPHY}

Achchuthan, S. and Kajananthan, R. (2012): A Study on Value Chain Analysis in Dairy Sector Kilinochchi District, Sri Lanka. Global Journal of Management and Business Research, Vol. 12, No. 21, pp.2249-4588.

Antony, K., Njoka, J.T., Kinyua, P.I.D. and Young, T.B. (2013): Characterizations of livestock manure market and the income contribution of manure trade in Mukogodo, Laikipia, Kenya. African Journal of Agricultural Research, Vol. 8, No. 46, pp.5864-5871.

Bourque, L. and Koroluk, R. (2003): Manure storage in Canada. Farm Environmental Management in Canada. http://publications.gc.ca/Collection/Statcan/21-021-M/21-021-MIE2003001.pdf

Ewusi-Mensah, N., Logah, V. and Akrasi, E.J. (2015): Impact of Different Systems of Manure Management on the Quality of Cow Dung. Journal of Communications in Soil Science and Plant Analysis, Vol.46, No. 2, pp.137-147. 
Harris, F. (2002): Management of manure in farming systems in semi-arid west africa. Experimental Agriculture, 38(2), 131-148. https://doi.org/10.1017/S0014479702000212

IFAD: (International Fund for Agricultural Development) (2007): Value chains, linking producers to the markets. https://fcrn.org.uk/sites/default/files/IFAD_Value_chains.pdf. retrieved 25/09/2019

Kaplinsky, R. and Morris, M. (2002): A Handbook for Value Chain Research. Institute of Development Studies. University of Sussex and School of Development Studies, University of Natal, http:// www. ids.ac.uklglobal.

Kelly, F. and Michael, L. (2014): Storing Manure on Small Horse and Livestock Farms. Rutgers, the State University of New Jersey. Fact Sheet FS1192.

Malhotra K. N., (2014): Basic marketing research, Pearson education limited, 4th edition, Edinburgh gate, England. pp.367-400.

MOA (Ministry Of Agriculture) (2014): Farm Practice Atmospheric environment Manure Storage and Use. British Columbia. Order No. 870.218-44: pp.1-3. http://www2.gov.bc.ca/.../farming...environment/...farming/farm-practices.com. On (1/8/2017).

MOA (Ministry Of Agriculture) (2015): Daily manure scraping management system for dairy farms. British Columbia. Fact sheet. Order No. 381.200-1.pp.1-4.

MOA (Ministry Of Agriculture) (2015): Sizing Dairy Manure Storage Structures. British Columbia. https:// www2.gov.bc.ca/assets/gov/farming-natural-resources-and-industry/agriculture-and-seafood/agricultural-land-and-environment/waste-management/manure-management/383000-1_manure_storage_structures.pdf

Mottet, A., de Haan, C., Falcucci, A., Tempio, G., Opio, C., Gerber, P., (2017): Livestock: on our plates or eating at our table? A new analysis of the feed/food debate. https://macaulaylab.berkeley.edu/ wp-content/uploads/2016/01/LivestockFeed2017.pdf

Muhereza, I., Pritchard, D. and Murray-prior, R. (2014): Utilisation of cattle manure and inorganic fertiliser for food production in central Uganda. Journal of Agriculture and Environment for International Development, Vol. 108, No. 2, pp.135-151.

Mustafa, E.; El Emam, M.; Abdelhadi ,O. and Salih, A. (2011): The contribution of dairying to household welfare of the small commercial dairy keepers in Khartoum North province (KNP), Sudan. Research Opinions in Animal and Veterinary Sciences, vol. 1(1): 55-59. https://www.researchgate.net/publication/258283677_The_contribution_of_dairying_to_household_welfare_of_the_small_commercial_ dairy_keepers_in_Khartoum_north_province_KNP_Sudan

Nabiswa, P. K. and Siamba, D. (2017): Effect of Marketing Strategies on the Dairy Value Chain Returns and Food and Nutrition Security in Bungoma County, Kenya. Journal of Agriculture and Veterinary Science, Vol. 10, pp.45-56.

NCAT (National Center for Appropriate Technology) (2014): Marketing Manure: A Value-Added Product for Small Operations. Available at http://www.attra.ncat.org. IP459. On (1/8/2017)

Ogejo, J.A. (2005): Manure Production and Characteristics. United state department of agriculture, National Institute of Food and Agriculture, New Technologies for Ag Extension project.

Porter, M.E. (1985): The Competitive Advantage: Creating and Sustaining Superior Performance. NY: Free Press. (Republished with a new introduction, 1998).

Powell, J.M., Mccrory, D.F. and Saam, H. (2005): Manure Collection and Distribution on Wisconsin Dairy Farms, 2044, 2036-2044. Available at https://www.doi.org/10.2134/jeq2004.0478

Van Zanten, H.H.E., Herrero, M., Hal, O.Van, Röös, E., Muller, A., Garnett, T., Gerber, P.J., Schader, C. and De Boer, I.J.M. (2018): Defining a land boundary for sustainablelivestock consumption.

Global Change Biology. https://doi.org/10.1111/gcb.14321

WBCSD: (World Business Council for Sustainable Development) (2011): Collaboration, innovation, transformation: Ideas and inspiration to accelerate sustainable growth - A value chain approach, p. 3 and 5 (emphasis added). 


\section{BIOGRAPHIES}

AMIRA A. AHMED Lecturer and active researcher in the Faculty of Animal Production University of Khartoum. BSc. Animal Production, MSc. Dairy production \& Technology.

NAHID M.T. FAWI Associate professor - University of Khartoum with a PhD in Marketing and a Freelance marketing consultant. Specialized in Agribusiness with focus on Agricultural marketing. Certified Trainer and head of Animal Production Training center in the University of Khartoum. A main speaker in several summits in Dubai, London and Khartoum. 